\title{
Vuoropuhelu Etelä-Amerikan nykymaisemasta
}

Hilja Roivainen

Andermann, Jens, Blackmore, Lisa \& Dayron, Carrillo Morell (toim.), Natura: Environmental Aesthetics After Landscape. Zürich: Diaphanes Verlag, 2018, 294 sivua.

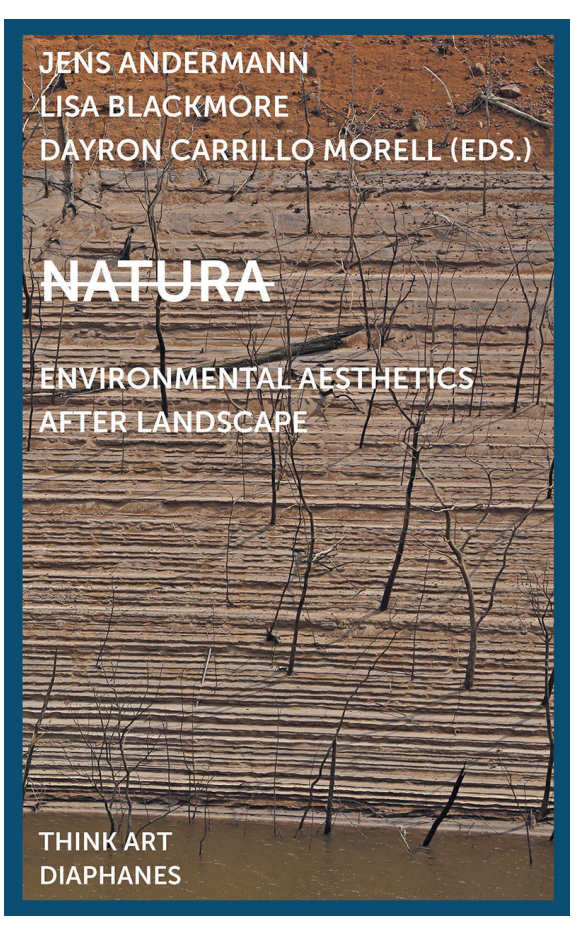

Kirja osallistuu kuvataiteen perspektiivistä nykyiseen kriittiseen keskusteluun luonnonvarojen roolista globaalissa talousjärjestelmässä. Kirjan kolmetoista esseetä ja johdanto kursivat yhteen kolonialismin historian ja 2000-luvun uuskolonialistisen luonnon resurssien taloudellisen hyötykäytön. Kirjassa kysytään, miten taiteilija voi auttaa pysäyttämään luontoa tuhoavia käytäntöjä - erityisesti Etelä-Amerikan teollistumiseen liittyvien maaoikeuskiistojen kontekstissa. Esseissä esitellään teosesimerkkejä bio- ja ekotaiteesta muun muassa erilaisina katsantokantoina luonnollisten elementtien, kuten kasvien, ilman ja veden toimijuuteen.

Kirja tuo uuden näkökulman viime aikoina vilkkaasti käytyyn keskusteluun ekokriittisestä taiteesta ${ }^{1}$ havainnollistamalla painokkaasti maisemaidean roolia luonnon valloittamisen mahdollistavana utooppisena tasona. Utooppinen maisema symboloi kirjassa ku- vatun ilmastonmuutoshuolen kautta luonnon hyväksikäyttöä. Esseet avaavat lukijalle modernin tieteen ja kapitalismin kehitykseen kytkeytyvää kolonialismin historiaa. Ne tulkitsevat kriittisesti uudelleen imperialismin värittämää maisemakuvaa ja luonnon valloittamista.

Esseekokoelma käy moniäänistä keskustelua eteläamerikkalaisesta ympäristökriittisestä "postmaisemataiteesta". Kirjan esittelemä nykytaide havainnollistaa kirjan toimittajan, kulttuurintutkija Jens Andermannin (15) sanoin "maiseman jälkeistä" ympäristöestetiikkaa. Toisin sanoen, artikkelikokoelma pyrkii kumoamaan kolonialistisen maisemakäsityksen ja tulkitsemaan kriittisistä näkökulmista modernissa tieteessä tehtyjä luonnon määritelmiä. Eurooppalaisten luoma maisemaidea on kirjoittajien mukaan tarjonnut alustan valloittajien unelmille. Esseet tulkitsevat 2000-luvulta käsin 1500-luvun käsitystä 
eteläamerikkalaisesta maisemasta Kolumbuksen löytämänä paratiisina - jota myös kirjassa esitellyt 1800-luvun kasvitieteelliset kuvaukset heijastavat. Tämä maisema näkyy kuvauksissa, joita eurooppalaiset löytöretkeilijät, seikkailijat, tutkijat ja maanriistäjät välittivät Etelä-Amerikan luonnosta.

Kompakti kokonaisuus runsaine kuvineen tempaa lukijan mukaansa. Taiteilijoiden ja tutkijoiden esseet vaihtelevat teoreettisista pohdinnoista yksittäisiä taideteoksia avaaviin teksteihin, mikä tekee lukukokemuksesta runsassisältöisen. Lyhyehköistä esseistä saa nopeasti monipuolisen kuvan muutoksista maiseman käsitteen ja maisemataiteen muodoissa 1600-luvulta 2000-luvulle ja niihin kytkeytyvistä oletuksista ihmisen ja luonnon suhteesta. Hakusanasto ja kuvaluettelo kirjasta tosin uupuvat.

Kirjaa voi lukea otoksena 2000-luvun ekotaiteesta ja ympäristöestetiikasta. Punaisena lankana kulkee kritiikki luontoa hyväksikäyttävää toimintaa, kuten geologista insinööritekniikkaa (geoengineering) kohtaan. Kirjassa esitellään muun muassa alkuperäiskansojen maaoikeuksiin kohdistuneita rikkomuksia sekä luontoa saastuttavaa öljynporausta Amerikoissa. Teos nostaa esiin eteläamerikkalaisen nykytaiteen luonnonsuojeluvisioita ja kytkeytyy näin kiinnostavasti imperialistisen maisemaidean tutkimukseen, josta saa kuvan esimerkiksi Denis E. Cosgroven teoksesta Social Formation and Symbolic Landscape (1998) tai William J. Thomas Mitchellin artikkelista "Imperial Landscape" teoksessa Landscape and Power (1994). ${ }^{2}$ Esseet erittelevät kuinka luontoa edelleen 2000-luvulla "valloitetaan" inmisen käyttöön. Esimerkiksi massiivinen maanmuokkaus luo utooppisen illuusion siitä, että luonto olisi hallittavissa.

Andermannin mukaan (15-16) esseekokoelma pyrkii "purkamaan modernin maiseman käsitteen" ja luonnon hallintaa korostavan maisemaidean. Maiseman historiallista rakentumista luetaan kriittisesti jälkikolonialistisesta perspektiivistä. Kirjassa kuvitellaan "maiseman jälkeisiä ja uusia tilallis-ajallisia elämänmuotoja" sekä luotetaan estetiikkaan niiden käsitteellistämisen ja "kokoon kyhäämisen" menetelmänä. Taiteen "epämääräinen laatu" tarjoaa Andermannin mukaan mahdollisuuden mukautua "alkuperäiskansojen epistemologioihin".

Ääni annetaan jälkikolonialististen maisemakäsitysten tutkijoille sekä kuvataiteilijoille, jotka havainnoivat Etelä-Amerikan kuin myös muiden maiden hankalia poliittisia tilanteita. Kirjaa varten kirjoitetuista esseistä esimerkiksi taidehistorioitsija Lisa Blackmoren "Colonizing Flow", filosofi Emanuele Coccian "The Cosmic Garden", kuvataiteilija-kirjoittaja-kuraattori Ursula Biemannin "Geomorphic Video" ja kirjallisuustieteilijä Oliver Lubrichin "Humboldtian Landscape" kumoavat vanhan maisemakäsityksen. Ne tarkastelevat muun muassa käsitteellistä nykytaidetta ja tulkintoja luonnon tilasta niin Brasiliassa, Ecuadorissa ja Venezuelassa, kuin myös Kanadassa tai Bangladeshin suistomaalla. Kirjoittajat uudelleentulkitsevat luonnon valloittamisen oikeuttavaa maisemaideaa muun muassa uusmaterialistisista teorioista käsin.

Kirjan aineisto koostuu myös taiteilija-aktivistien teoksista sekä saksalaisten tiedemiesten kolonialismin aikaisista piirustuksista. Nämä 1800-luvun kasvitieteilijä-taiteilijoiden kuvaamat luonnonmuodot havainnollistavat kirjassa imperialistista maisemaa ja ne asetetaan dialogiin eteläamerikkalaisten nykytaiteilijoiden teosten kanssa.

Taustaltaan eteläamerikkalaisten sekä eteläamerikkalaisten kanssa yhteistyötä te- 
kevien taiteilijoiden ja tutkijoiden esseissä käsitelty nykytaide kommentoi installaatio-, video- sekä maataiteen menetelmin erityisesti ympäristökonflikteja. Esimerkiksi Ursula Biemann, kuvataiteilija-tutkija Maria Thereza Alves ja kirjailija-aktivisti Genaro Amaro Altamirano ottavat osaa "ylirajaiseen" (translocal) aktivismiin (14). He tarkastelevat, miten maisemaideaan sisältyvä katsojan ja katseen kohteen välinen vastakkainasettelu voidaan kumota bio- ja ekotaiteessa.

\section{Uusmaterialistisia näkökulmia}

Kirja problematisoi eurooppalaisten luomaa maiseman ideaa muun muassa uusmaterialististen teorioiden avulla. Uusmaterialistinen katsantokanta näkyy kiinnostuksena aineen ja ei-inhimillisen, kuten kasvien ja elottomien luontokappaleiden, tai vaikka vesipatojen, toimijuuteen maailmassa ja osana ilmastonmuutosta.

Biotaiteella tarkoitetaan kirjassa taiteellisia interventioita, jotka tutkivat nykyistä tilannetta, jossa alkuperäiskansojen käyttämistä lääkinnällisistä menetelmistä ja lääkekasveista on tullut osa uuskolonialistista globaalin kapitalismin järjestelmää. Esimerkkeinä biotaiteesta Andermann (265, 273-275) mainitsee torakoille rakennetun labyrintin (Habitat-laberinto para cucarachas, 1971) tai muut teokset, joita Luis Fernando Benedit on toteuttanut luonnontieteellisen laboratoriotyöskentelyn keinoin. Myös muun muassa Eduardo Kacin Natural History of the Enigma (2003-2008) ja Genesis (1999) luovat hybridejä, kuten kukkia tai kolibakteereita, joihin on risteytetty taiteilijan omaa DNA:ta.

Rosalind Kraussin klassikkotekstin "Sculpture in the Expanded Field" (1979) mukaan "kuvanveiston laajentunut kenttä" on ominainen postmodernin jälkeiselle taiteelle, jossa taiteilija liikkuu monimerkityksellisellä alueella. ${ }^{3}$ Monet esseekokoelmassa kuvatuista taideteoksista kuuluvat myös Kraussin analysoimaan perinteeseen. Nykytaiteilija toimii erilaisissa asemissa ja organisoi työnsä toisin kuin perinteinen kuvanveistäjä. Natura-kirjassa esitellyt taiteilijat tekevät esimerkiksi tutkimustyötä aktivistien ja kansalaisorganisaatioiden kanssa ja edistävät näiden tavoitteita muun muassa dokumentaation keinoin. Kirjoittajat tulkitsevat taiteen funktionaaliseksi työkaluksi, jonka avulla voidaan määritellä uudelleen maaoikeuksia ja alkuperäiskansojen asemaa. Erityisesti jälkimmäiseen paneudutaan kirjassa maisemaidean purkamisen kautta.
Kuten kulttuuriteoreetikko Malcolm Miles tekemässään katsauksessa Eco-Aesthetics: Art, Literature and Architecture in a Period of Climate Change (2014), Natura-kirja muodostaa valikoitujen teosesimerkkien kautta kuvan 2000-luvun ympäristöestetiikasta. ${ }^{4}$ Kirja osoittaa tapoja, joilla taiteilijat ovat puuttuneet luonnon hyväksikäyttöön. Taidehistorioitsija-aktivisti Yates McKeen mukaan ekokritiikki on saanut vaikutteita amerikkalaisesta transsendentaalisesta koskemattoman luonnon ideaalista ja pyrkii pitämään luontoa suojassa inmisen aiheuttamalta tuholta. Viime vuosikymmeninä ympäristöaktivismi ja ekokritiikki ovat korostaneet "ekologisen tuhon välttämistä". Samalla ne ovat alkaneet painottaa myös "sosiaalisen eriarvoisuuden", kuten "etnisten ryhmien, luokan ja sukupuolen" roolia luonnonsuojelussa. $^{5}$

\section{Kolonialistinen maisemakäsitys}

Oliver Lubrichin essee "Humboldtian Landscape" nostaa esiin eurooppalaisen tieteen roolin kolonialistisen maisemakuvan muodostumisessa Etelä-Amerikan kontekstissa. Kuten hän toteaa, maisema-sana merkitsee juuri eurooppalaista käsitystä luonnosta. 
Lubrich (73) viittaa vuoden 1780 Britannican määritelmään maisemasta maalaustaiteen kuvaamana pastoraalina. Tämä kuvaus sisältää hänen mukaansa "tieteellisiä, poliittisia ja ideologisia sävyjä". Lubrich ottaa tapausesimerkikseen berliiniläisen tieteilijä-taiteilija Alexander von Humboldtin (1769-1859) idean maisemasta, joka kuvaa trooppisen luonnon kohtaamista Espanjan siirtomaissa vuosina 1799-1804.

Lubrich (74) jakaa Humboldtin maiseman idean kuuteen näkökulmaan: (1) "symbolinen ja poliittinen", (2) "esteettisen ihailun ja tieteellisen tarkkailun kohde", (3) "haaste tieteiden väliselle tulkinnalle", (4) "ekosysteemi jo ennen omaa aikaansa" (avant la lettre), (5) "akustinen" ja (6) "julkisen multimediainstallaation demokraattinen visio". Lubrich erittelee jokaisen katsantokannan ja tuo esiin niiden hyödyn monitieteiselle maisematutkimukselle.

Humboldtin maisemaidea vertautuu esseessä aikakauden poliittiseen tilanteeseen. Historiallisten dokumenttien avulla Lubrich osoittaa Humboldtin kriittisen suhtautumisen Etelä-Amerikan valloituspyrkimyksiin Napoleonin aikana. Hän esittää Humboldtin kolonialismin kriitikkona, joka monitieteisellä näkemyksellään oli edistämässä maisemakuvan sekä tieteen kehitystä niin Euroopassa kuin Etelä-Amerikassa. Lubrich korostaa, että Humboldt loi kehittämällään "taidemaantieteellään" kulttuurisia vaikutuksia maisemamaalauksen eurooppalaiseen traditioon.

Lubrich $(86-87,89)$ tulkitsee Humboldtin maiseman monitieteisenä käsitteenä. Siinä yhdistyvät niin kasvitieteilijän, geologin, meteorologin, taiteilijan, historioitsijan, yhteiskuntatieteilijän kuin maantieteilijänkin katseet luontoon. Hän määrittää Humboldtin maisemat ekologisiksi, koska niissä visualisoidaan maisemaa eri näkökulmista. Lubrich korostaa filosofi Michel Foucault'ta lainaten kuinka Humboldtin piirrokset eteläamerikkalaisista maisemista ovat tieteellisen kehityksen tunnus ja osoitus siirtymästä staattisen taksonomisesta lajien jaottelusta "dynaamiseen historiallistamiseen". Humboldt "muutti luonnonhistorian tieteidenväliseksi muuttoliikkeen tutkimukseksi".

\section{Veden lupa kulkea}

Lisa Blackmore näyttää "Colonizing Flow" -esseessään lukijalle puolestaan kuinka Venezuelan Orinoco-joen alueesta on tullut luonnon valloittamisen symboli, joka yllä-
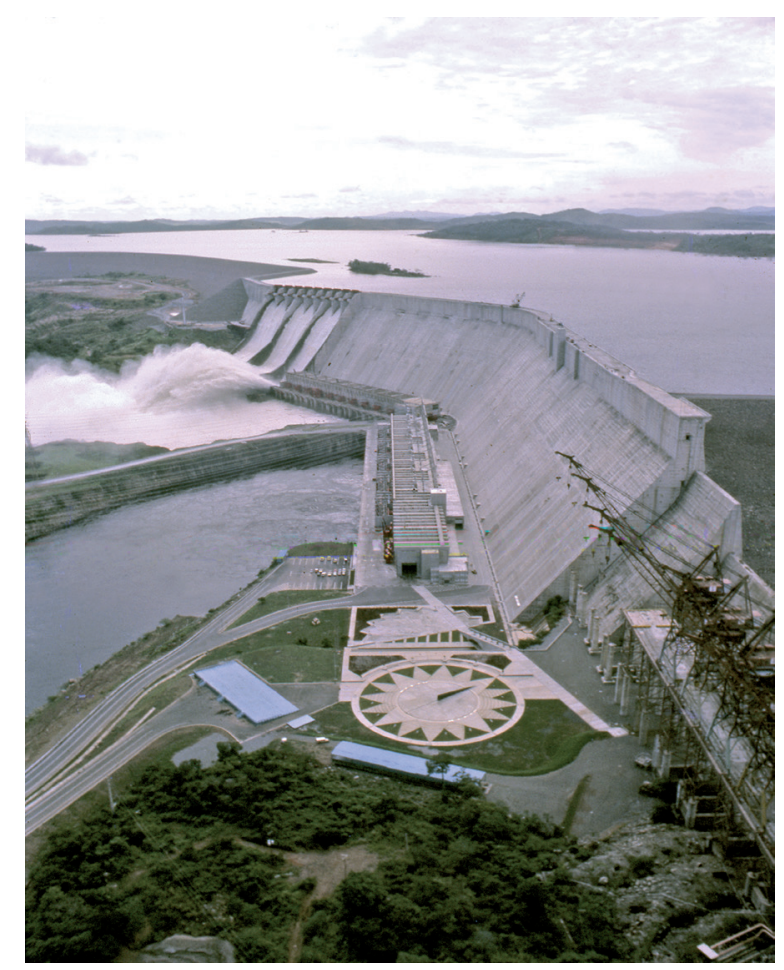

Kuva 1. Central Hidroeléctrica Simón Bolívar (formerly Raúl Leoni). Represa del Guri, Bolívar State, n. 1978. Taka-alalta etu-alalle: pato-allas, patoaukko, turbiinihuone, patomuuri, Plaza del Sol y la Luna, ja patomuurin laajennusrakennelma. Kuva: Fernando Irazábal @ Archivo Fotografía Urbana (Diaphanes). 
pitää kuvitellusti Eldoradoon johtavaan jokeen kytkettyjä luonnon hallinnan mielikuvia. Blackmore kuvailee esimerkiksi luonnon valloituksesta Orinoco-joella sijaitsevan maailman kolmanneksi suurimman Gurin vesivoimalaitoksen (Central Hidroeléctrica Simón Bolívar, aiemmin Raúl Leoni). Sen hydrologinen infrastruktuuri ja tarkkailumenetelmät ovat keinotekoisia. Padot horjuttavat veden luonnollista kulkua ja ovat Blackmoren mukaan lisänneet Venezuelassa tulvien ja kuivien jaksojen jyrkkää vaihtelua. Blackmoren sanoin vesisähkö tekee etäisistä luonnon resursseista urbaaneja inmiskeskittymiä palvelevia voimalähteitä ja Jane Bennettin määrittämiä "yksittäisten elementtien ryhmittymiä" eli koosteita.

Blackmore tulkitsee Gurin vesivoimalaa koosteena (assemblage), jonka ovat muokanneet insinööritaito, voimalaan toteutettu taide ja ei-inhimillisten toimijoiden, kuten veden, "väreilevä materia". Valtio teetätti 1970-luvulla voimalaan tilaustyönä postkineettistä taidetta, joka toimii Blackmoren tulkinnassa ympäristöesteettisesti vastuullisen ja kestävän Orinocon jokialueen kehittämisen suunnannäyttäjänä. Taide nimittäin osoittaa katsojalle joen materiaalisen koostumuksen.
Carlos Cruz Diezin teokseen Kromaattiset ympäristöt (Ambientación cromática, 19771986) kuuluvassa voimalan konehuoneessa sijaitsevassa paneelityössä 1200 valolamppua vaihtelevat väreissä ja kiinnittävät huomion vesisähköön. Blackmoren (190-191, 194, 196) mukaan teoksen virtaavat nesteet ja huomiot veden liikkeestä sekä vaihtuvista kromaattisista sävyistä korostavat modernia kieltä, jota teknologiat käyttivät järjestäessään ja maisemoidessaan infrastruktuureillaan vettä sähkövirran lähteeksi. Blackmore luonnehtii Gurin taideteoksissa ja voimalassa näkyvää inhimillisen ja ei-inhimillisen jatkuvuutta "postkineettiseksi vesisähköiseksi koosteeksi", joka johdattaa kohti kestävämpiä taidemuotoja. Teokset ehdottavat, että luonto on ympärillämme ja sisällämme operoiva dynaaminen toimija, eikä pelkästään objekti.

Hydrologisen hallinnan osoittamisesta kuten valtion öljyvaroin rakentamasta Gurin vesivoimalasta, tulee Blackmoren (176, 179-181, 183) sanoin "teknologisen ylevän" ja valtion symboli, jossa yhdistyvät "veden ja öljyn ekologiat". Blackmoren mukaan pato on "jumalallisen luonnon" haltuunoton ja sen tarjoaman kehityksen maamerkki. Pato luo mielikuvaa vesivoimalla toimivasta valtiosta. Blackmore lukee Venezuelan nykyisen "hydrologisen monarkin" symboloituvan siinä, miten valtio kykeni ohjailemaan jokialueen virtaukset tehdas- ja kaivostoimintojensa hyväksi.

Maiseman idean Blackmore näkee Gurissa ja sinne toteutetuissa taideteoksissa liikkuvana tilana. Se hahmottuu etenkin materian tasolla - luontona, joka on meidän sisällämme ja virtaa ympärillämme. Tällaisen uusmaterialistisen luonto- ja maisemakäsityksen Blackmore esittää vaihtoehdoksi 1800-Iuvun kolonialistiselle maisemakuvalle sekä 1900- ja 2000-lukujen teollistumiseen sisältyvälle luonnon kontrollin logiikalle.

Gurin postkineettiset teokset jatkavat ekotaiteen perinnettä. Esimerkiksi Hans Haacke teki ekokriittisen kannanoton Reinjoen likavesipäästöistä installaatioteoksessaan Rhine-Water Purification Plant (1972)

ja Tue Greenfort herätti vastaavasti keskustelua epäeettisistä pullovesimarkkinoista BONAQUA Condensation Cube -installaatiollaan (2005/2013). Ekologian, talouden ja instituutioiden välinen yhteys kytkeytyy näin vesisymboliikkaan. Idea taiteesta yhtenä ekosysteeminä korostuu teosten koostuessa kapitalismin hyväksikäyttämistä, rajallisista luonnon materiaaleista (vedestä) 


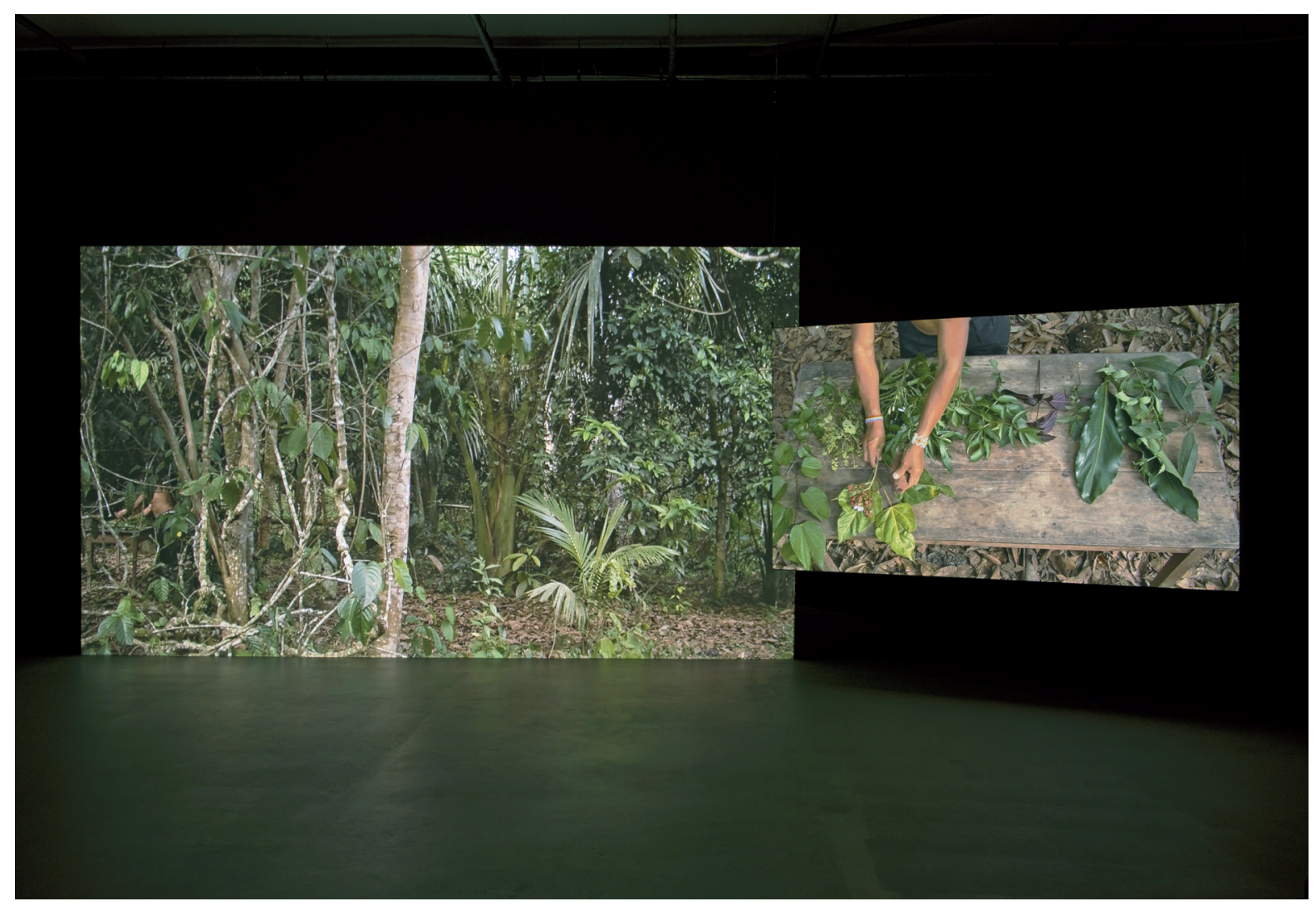

Kuva 2. Ursula Biemann ja Paolo Tavares, stillkuva videoteoksesta Forest Law - Selva jurídica, 2014. Kaksi samanaikaisesti pyörivää videota paljastavat visuaalisella kolmiulotteisuudellaan maiseman, jota asuttavat kaikenlaiset aistivat olennot todellisuuden eri ulottuvuuksissa. Kuva: @Diaphanes (East Lansing: Broad Art Museum/Michigan State Univeristy, 2014). ja alleviivatessa taideteoksen osuutta tässä materiaalien kiertokulussa.

\section{Luonnon oikeudet}

Ursula Biemann pohtii taasen "Geomorphic Video" -esseessään, kuinka hänen tuottamansa elokuvat Deep Weather (2013) ja Forest Law (2014) ovat environmentalismia. Hän kysyy: miten järjestää uudelleen suhde taiteilija-tekijän ja ei-inhimillisen maailman välillä? Biemann nostaa Deep Weather -videoesseessään esiin Pohjois-Kanadan fossiilikerrostumien kaivuutöitä sekä nousevan merenpinnan torjuntatoimia Bangladeshin suistomaalla. Kanadan öljynkaivuun bitumiprosessoinnin tuottamat myrkylliset jätteet ovat levinneet järviin, joiden tieltä on raivattu alkuperäiskansojen metsät. Savisäkeistä rakennetut suojapadot, jotka torjuvat Bengalin lahden suistomaan vedennousua, ovat puolestaan osoitus ihmisen maisemointitöistä ja ovat seurausta planetaarisessa mittakaavassa nousevasta merenpinnasta. Deep Weather -teos esittää maapallon "suljettuna järjestelmänä".

Biemannin mukaan alkuperäiskansojen näkemys kosmoksesta korostaa eettistä ja oikeudellista järjestelmää, jossa luonnol- 
la on inmisoikeuksille yhtäläiset oikeudet. ${ }^{6}$ Biemann viittaa tässä ecuadorilaisen antropologi Eduardo Kohnin ajatteluun. ${ }^{7}$ Kohn tutustuttaa lukijansa maisemahistorian kehitykseen vaikuttaneeseen globaaliin kapitalismiin, kuten mineraalien ja fossiilien tuotteistamiseen. Hän ehdottaa uudenlaista luonnon elementtien materiaalisuuden tiedostamista, jossa ymmärretään, miten geopolitiikka, alkuperäiskansat ja luonto ovat toisiinsa nivoutuneita.

Biemannin ja arkkitehti Paulo Tavaresin multimediateoksessa Forest Law - Selva juridica (2014) kaksi keskelle Amazonin sademetsää sijoitettua videokameraa todistavat tällaista ilmastonmuutoksen aiheuttamaa tilannetta ja siihen liittyviä maaoikeuskiistoja, metsätuhoa ja lajien katoa. Videoteos korostaa sademetsien globaalia merkitystä ekosysteemille maapallon aineenvaihdunnan ylläpitäjänä, kuten maan viilentäjänä ja siten koko sivilisaation kannattelijana.

Maisema tuodaan Biemannin (46-47, 49) sanoin videossa "takakulissin asemasta päärooliin". Teos tuottaa uudenlaisen perspektiivin maisemaan zoomaamalla kasvillisuuden seasta löytyviin "kuparijätekasoihin, metsän henkiin, tieteilijöihin, alkuperäiskan- sojen neuvostoihin [...tai] lääkekasveihin". Se näyttää siten metsässä tapahtuvan monimuotoisten käytäntöjen ekologian, jonka Biemann nimeää kosmopoliittisiksi harkinnoiksi (cosmopolitical considerations). Hän kysyy: kuinka laki, kosmologia ja ekologia voisivat hahmottaa maailmanlaajuisen jonakin kaikille yhteisenä? Ja kuinka esteettinen toiminta voisi muodostaa toiveita yhteiseksi tehtävästä maailmasta? Luonnonmaantieteellisen videotaiteensa harjoittamisen hän ehdottaa olevan yksi tällainen hidastava tietämisen tapa, joka mahdollistaa "vaihtuvia ajallisuuksia". Toiminnan avulla voidaan luoda "erilaista kosmosta".

Emannuele Coccian "The Cosmic Garden" -essee puolestaan huomioi kasvien tutkitusti omaaman älykkyyden ja aistikyvyn. Coccia (21, 28-29) demonstroi, kuinka kasvit ovat itseasiassa inmisen kulttuurin pohja: ruoka, huonekalut, vaatteet, polttoaineet ja lääkkeet saavat niistä materiaalinsa. Hän osoittaa kasvien 99-prosenttisen osuuden maapalIon biomassasta ja väittää, että kasvitieteen yksi alahaara voisi olla kosmologia. Maailma on yksi suuri puutarha ja yhtä ilmastoa. Kasvit luovat ilmastoa tuottamalla happea ja ne myös levittäytyvät maailmanlaajuises- ti ilmavirtausten mukana. Coccia näkee tämän ilmakehän, jossa ilma ja kasvillisuuden ainekset leviävät, metafyysisenä tilana. Hän olettaa, että kaikkien eliöiden olemista maailmassa yhdistää koko maailman kattava yksi suuri ilmasto (atmosphere). Sen välityksellä subjektin ja objektin sekä maailman välillä tapahtuu "värähtelyä". IImasto on tila, jossa "luontoa ja kulttuuria ei voi erottaa toisistaan". Oleminen maailmassa on sama asia kuin "yhteisen ilmakehän hengittäminen".

\section{Esteettinen aktivismi}

Kirjoittajien puinti maisemasta utooppisen kolonialismin alustana on esimerkkeineen havainnollistava. Lubrichin, Blackmoren, Biemannin ja Coccian, kuten muidenkin kirjoittajien, esseissä utooppinen maisema ymmärretään ekokriittisen ilmastohuolen kautta. Kirjoittajat perkaavat Cosgroven (1998) ja Mitchellin (1994) tunnistaman imperialistisen perspektiivin rakentumista etenkin 1800-luvun siirtomaavallan ajan maisemakuvauksiin. Maisema liittyy monimutkaisiin luonnon hyväksikäytön ja maaomistuksen kiistoihin. Kirja jatkaa viimeaikaisia maisemaidean uudelleen tulkintoja nykytaiteessa. 
Kirjoittajat etsivät tapoja torjua modernin markkinatalouden käynnistämä, luontoa vahingoittava hyväksikäyttö. Ihmisen rooli maiseman esteettisenä tarkastelijana myös problematisoidaan. Taiteilija näytetään vuorovaikuttamassa luonnontieteilijän tai alkuperäisasukkaan tavoin luonnon kanssa. Kirjassa esitelty taide etsii ratkaisuja siihen, miten luonnon kulutusta voitaisiin viedä kestävämpään suuntaan. Tämä aktivismitaide näyttää kannustavan aineettomaan relaatioestetiikkaan. ${ }^{8}$ Kysymykseksi jää, kuinka länsimaisen maisemamaalauksen traditioihin viittaavan nykymaisemataiteen tulisi tällaisen aktivismin kontekstissa asemoitua.

\section{Viitteet}

1 Ks. esim. Thomas J. Demos, Decolonizing Nature: Contemporary Art and the Politics of Ecology

(Berlin: Sternberg Press, 2016); Thomas J. Demos, Return to the Postcolony: Specters of Colonialism in Contemporary Art (Berlin: Sternberg Press, 2013) ja T.J. Demos, "Art After Nature. T. J. Demos on the post-natural condition", Artforum, April 2012: 190197, luettu 21.7.2019, http://tomorrowmorning net// texts/demos artafternature artforum.pdf.

2 Denis E. Cosgrove, Social Formation and Symbolic Landscape (Wisconsin: The University ofWisconsin Press, 1998) ja William J. Thomas Mitchell, "Imperial Landscape", teoksessa Landscape and Power, toim. Mitchell, William J. Thomas (Chicago: University of Chicago Press, 1994).

3 Rosalind Krauss, "Sculpture in the Expanded Field", October, 8 (Spring)/1979: 30-44. Ks. s. 38 ja 41-44. 4 Malcolm Miles, Eco-Aesthetics: Art, Literature and Architecture in a Period of Climate Change (London: Bloomsbury Publishing, 2014)

5 Yates McKee, "Art History, Ecocriticism, and the Ends of Man", Oxford Art Journal, 34 (1, March)/2011 123-129, ks. s. 125. Ks. myös Alan C. Braddock \& Charles Irmscher (eds.), A Keener Perception Ecocritical Studies in American Art History (University of Alabama Press: Tucaloosa, 2009).

6 Biemann mainitsee muitakin esimerkkejä, kuten Michael Serresin The Natural Contract -teoksessa (Ann Arbor: University of Michigan Press, 1995) tunnistaman ihmisen ja luonnon välisen sopimuksen. 7 Eduardo Kohn, How Forests Think (Stanford: University of California Press, 2013).

8 Bourriaud, Nicolas, Relational Aesthetics, Trans.

Simon Pleasance \& Fronza Woods (Dijon: Les presses du réel, 2002)
Hilja Roivainen on kuvataiteen

maisteri, joka viimeistelee Turun

yliopiston taidehistorian oppiaineessa

monografiaväitöskirjaa utooppisesta

maisemamaalauksesta. Kirja-arvio on

osa TOP-säätiön, Turun Yliopistosäätiön,

Oskar Öflunds Stiftelse sr:n ja Koneen

Säätiön rahoittamaa "Utooppinen

maisema pohjoismaisessa 2000-luvun

maalaustaiteessa" -väitöskirjaprojektia.

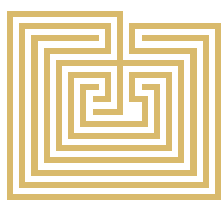

